\title{
Evidence of Contractor Compliance Document
}

National Cancer Institute

\section{Source}

National Cancer Institute. Evidence of Contractor Compliance Document. NCI

Thesaurus. Code C115690.

Records validating that a third party meets all criteria to fulfill a contractual obligation for the duration of a clinical trial. 